\title{
Teacher Training As A Means to Instil Sustainable Environmental Behaviour among Future Teachers: A Systematic Literature Review
}

Aini Arifah binti Abdul Karim, Sabrina Abdullah, Ahmad Fauzi Mohd Ayub, Amir Hamzah Sharaai

To Link this Article: http://dx.doi.org/10.6007/IJARBSS/v11-i4/9652

DOI:10.6007/IJARBSS/v11-i4/9652

Received: 12 February 2021, Revised: 15 March 2021, Accepted: 31 March 2021

Published Online: 13 April 2021

In-Text Citation: (Karim et al., 2021)

To Cite this Article: Karim, A. A. binti A., Abdullah, S., Ayub, A. F. M., \& Sharaai, A. H. (2021). Teacher Training As A Means to Instil Sustainable Environmental Behaviour among Future Teachers: A Systematic Literature Review. International Journal of Academic Research in Business and Social Sciences, 11(4), 165-180.

Copyright: (c) 2021 The Author(s)

Published by Human Resource Management Academic Research Society (www.hrmars.com) This article is published under the Creative Commons Attribution (CC BY 4.0) license. Anyone may reproduce, distribute, translate and create derivative works of this article (for both commercial and non-commercial purposes), subject to full attribution to the original publication and authors. The full terms of this license may be seen

at: http://creativecommons.org/licences/by/4.0/legalcode

Vol. 11, No. 4, 2021, Pg. 165 - 180

Full Terms \& Conditions of access and use can be found at http://hrmars.com/index.php/pages/detail/publication-ethics 


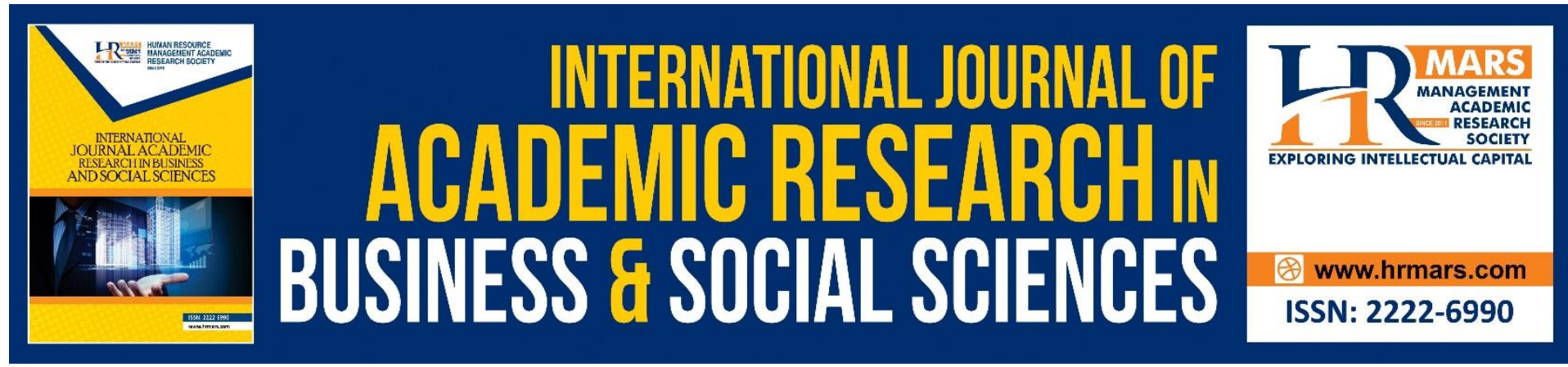

\title{
Teacher Training As A Means to Instil Sustainable Environmental Behaviour among Future Teachers: A Systematic Literature Review
}

\author{
${ }^{1}$ Aini Arifah binti Abdul Karim, ${ }^{2}$ Sabrina Abdullah, ${ }^{3}$ Ahmad Fauzi \\ Mohd Ayub, ${ }^{4}$ Amir Hamzah Sharaai \\ ${ }^{1,2,4}$ Faculty of Forestry and Environment, UPM, ${ }^{3}$ Faculty of Educational Studies, UPM \\ Email: ainiarifah@gmail.com, yuekming@upm.edu.my, afmy@upm.edu.my, \\ amirsharaai@upm.edu.my
}

\begin{abstract}
Teachers training is considered part of human resource development and indispensable in the realization of educational goals. Teacher training carries an important role in the human resources development especially in preparing the citizens of the nation into becoming an individual with sustainable behaviours. Much research has been done in studying how teacher training helps in changing their behaviour towards sustainability and love towards the environment. Few systematic reviews have been carried out on the sustainability in the educational sector. Education for sustainable development undeniably establishes the society's need for some transformation within the education sector; especially in the training of the teachers prior to their pursuit in embarking as real teachers. It is inevitable that teacher education has become a priority for orienteering the teachers in terms of sustainability. The present article aims to analyse the existing literature on pre service teachers' education towards the impact of change in the behaviour. This review is guided by the PRISMA statement (Preferred Reporting Items for Systematic reviews and Meta-Analyses) review method. A systematic review of the Scopus and Web of Science databases resulted in 19 related studies. Further review of these articles resulted in 4 major themes which are Measurement, Implementation, Factors and Methods/ Teaching Strategies. These 4 themes further produced 15 outcome variables. Several recommendations are highlighted related to use NVivo or Atlas. Ti as an analysis tool and to practice complimentary searching techniques such as citation tracking, reference searching, snowballing and contacting experts.
\end{abstract}

Keywords: Sustainable Environmental Behaviour, Education For Sustainable Development, Teacher Training, Systematic Literature Review

\section{Introduction}

The aim of this article is to examine training and development of teachers and how it can enhance their sustainable environment behaviour in Malaysia. Malaysia as a developing country has always encouraged their citizens to be more inclined towards taking care of the ageing planet, yet Malaysians have low to moderate level of understanding on environmental issues (Baniah, 2015). Research statistics have also reported that overall Malaysia's 
environmental performance reduced significantly in the past 10 years (EPI, 2006-2016). A nationwide study done by Mei, Wai \& Rahmalan Ahamad (2017) discovered that Malaysian's environmental awareness and behaviour do not seem to be positively correlated which implies that a strong environmental awareness level does not indicate greater environmental behaviour level. The relatively low sustainable environmental behaviour of the citizens of Malaysia in recent times has led to this study.

In order to develop a life in perfect harmony eco systemically, it is crucial to prepare the people with sufficient skills, knowledge, values, capabilities and dispositions. (Chinedu, 2018). This entails an emergence of Education for Sustainable Development (ESD) which can instill transformative learning process for students, teachers, and school systems with new knowledge. In fact, new ways of thinking are also necessary to achieve prosperity in the economic field. Furthermore, producing responsible citizenship is vital as the guardian of universe. Education is the most appropriate tool in developing these skills, knowledge, values, capabilities and dispositions that are necessary for Sustainable Development as agreed upon by many leaders. Therefore, Education for Sustainable Development (ESD) becomes crucial to realizing the goal of Sustainable Development of increasing a nation with sustainability literacy and conscious about the health of the living ecosystem.

The education system needs to be sustainability-oriented. This entails more training for individuals towards the sustainability of the environment. The change needs to happen by empowering the citizens and well-informed in producing environmentally active citizens. Thus, leading towards transformation of behavior involves the whole communities. (Ferreira, 2013).

Education for sustainable development is implemented to assist in the improvement of behaviour and lifestyles among citizens in the community as highlighted by Huckle and Sterling (1996), namely economy, environment and society. In 1987, the Brundtland Report defined sustainable development as a development that meets the needs of the present without compromising the ability of future generations to meet their own needs (Papuziński, 2018)

Teacher training carries an important role in the human resources development especially in preparing the citizens of the nation into becoming an individual with sustainable behaviours. Much research has been done in studying how the education of the future generation helps in changing the behaviour towards sustainability and love towards the environment. Nevertheless, it is crucial for the teachers to be adequately educated so that they can perform their role and carry out their responsibilities in their career as a role model amongst their respected students. Hence, it is substantial for the teachers to receive quality education as to become an important catalyst for sustainable development because literally most knowledgeable and skilled person in micro and macro activities are shaped by the the contribution of the teachers (Namunga, \& Otunga, 2012)

Teachers' role in the field of education require sufficient knowledge to be able to perform their roles and responsibilities. There are several varieties of educational programs for teachers. This involves both in-service teachers as well as preservice teachers. It is inevitable that teachers are significant individuals in which their contribution to optimize the wellbeing of the social, economic and political factors of a country (Namunga, \& Otunga, 2012). The demand for more educators in the nation resulted in the growth of teacher education programmes. This shows that teacher education is very important in driving and 
moving education for sustainable development which literally shape and develop in some ways by the contribution of a teacher. Therefore, it is crucial that teacher education programmes are shaped in a certain manner as to increase their effectiveness on the future generation, for future's sense of humanity. This paper reviews the various articles that discussed about the pre service teachers' studies on their consciousness and behaviour towards environment sustainability.

\section{Research Question}

To develop a systematic review, the literature study is geared by the main research question, specifically. What are the actions taken by teacher education institutions in the effort of enhancing pre service teachers' behaviors towards environmental sustainability? Therefore, this study is focusing on the programs and methods in which pre service teachers are trained by the institutions

\section{Objectives}

Considering the shortcomings and based on the research question, the main focus of this study is to review the existing literature on pre service teachers' behaviour towards sustainable environment. This paper seeks to find all the studies related to the pre service teachers all across the globe and how the institution of their training address the need to enhance and empower these future teachers to become someone who cares for the earth and behave in a sustainable environmental manner thus act sustainably in their career as a teacher. Although there are a lot of studies on environmental sustainability among the pre service teachers, efforts to systematically review these studies are scarce. This article aims to narrow down the gap in understanding and identifies as well as characterising the sustainable behaviour pattern among the pre service teachers. Reports on environment sustainable behaviour in the peer reviewed literature are refereed as proxy of behaviour, indicating that this article offers a general baseline overview of behaviourism. The work fills an important gap in the literature, with most systematic review examining the sustainable environmental behaviour on other than pre service teachers for example higher education students, secondary school students or even primary school students or concentrated on inservice teachers. Therefore, this study is vital in determining the sustainable environment behaviour among pre service teachers across the whole world.

\section{Methodology}

This paper employed a review strategy known as the systematic literature review. This type of review offers a more precise and organised manner and it presents systematic procedures for analysing research studies (Petticrew \& Roberts, 2008; Pickering \& Byrne, 2014). Furthermore, Evans, Stevenson, Lasen, Ferreira, and Davis (2017) also elaborated that this process enables researchers to become more transparent in the reviewing procedure when sourcing, evaluating, analysing and synthesising the results of relevant researches as to ensure that the process can be replicated by others. This approach was applied to primarily explore any perspectives in the field of sustainability amongst pre service teachers. Besides, this paper also sought to answer research questions that relate to how the ideologies of sustainability are being implemented in the courses for pre service teachers across the globe and how teachers are being taught about sustainability prior to endeavouring their career as future teachers. The systematic review approach gives a more explicit methodological procedure as to come up with a synthesis of evidence. Nevertheless, researchers do 
acknowledge any subjectivities in doing the interpretation as well as the limitations as a result of the provided information or otherwise have been excluded by the authors.

In this section the method used to retrieve articles related to education for sustainable development among pre service teachers is discussed. In reviewing the articles, a specific method called PRISMA is used. Via this method, two main resources which are Scopus and Web of Science were used to run the systematic review, eligibility as well as exclusion criteria, methods were utilized in processing the reviews which includes identification process, screening process and eligibility, and last but not least, data abstraction and analysis.

\section{Prisma}

The reviewing process was guided by the PRISMA Statement (Preferred Reporting Items for Systematic reviews and Meta-Analyses). Most of the time, PRISMA is used within the context of management field. Sierra-Correa and Cantera Kintz (2015) elaborated that PRISMA offers three unique advantages which includes:

1) it defines a clear research questions that allows a systematic research

2) it can identify certain inclusion and exclusion criteria

3) it examines a large database of scientific literature in a specific time.

The PRISMA Statement attempts for accurate search of terms related to preservice teachers' response to sustainability and its impact as well coded information for future management reviews.

\section{Resources}

In the process of reviewing these articles, two main journal databases were used (Scopus and Web of Science). Web of Science (WoS) is a powerful database which consist of N33,000 journals with a coverage of 256 disciplines including all the subjects that are related to sustainability studies, interdisciplinary social sciences, social issues and environmental education. It has over 100 years of comprehensive back file as well as citation data, which is established by Clarivate Analytics which is ranked by three separate measures: citations, papers, and citations-per-paper. The second database used in this review is Scopus and is one of the largest abstract and citation databases of peer-reviewed literature with N22,800 journals from over 5,000 publishers across the globe. Scopus consists of diverse subject areas such as environmental sciences, social science, engineering and medical sciences.

\section{Systematic Review Process}

The systematic review process was performed in December 2018 and the whole process involved four stages. The first stage was identifying the keywords that was used for the search string. By referring to previous studies and also thesaurus, keywords which are similar and closely related to sustainability and preservice teachers were used (Table 1). After thorough screening, there were two articles that needs to be removed due to duplicity.

The next stage of the reviewing process was thorough screening. Out of 660 articles that were eligible to be reviewed, about 563 articles were taken away. The third stage is eligibility, where the full articles were accessed. After a close examination, another 78 articles were removed as some did not focus on preservice teachers practice on sustainable environment, and were not empirical articles, also it did not focus on sustainability practices or did not focus on preservice teachers. The final stage of review process came to a total of 19 articles that were carefully analysed using qualitative analysis (see Fig. 1). 


\section{Identification}

Table 1

Search string identification for keywords

\begin{tabular}{|c|c|}
\hline Database & Search String \\
\hline Scopus & $\begin{array}{l}\text { ALL ( ( "preservice teacher*" OR "preservice educat*" OR "preservice } \\
\text { trainer*" OR "student teacher*" OR "teacher student*" OR "future } \\
\text { teacher*" ) AND ( "sustainab* } \\
\text { literac*" OR "sustainab* } \\
\text { conscious*" OR "sustainab* citizenship*" OR "sustainab* behavi*r*)) }\end{array}$ \\
\hline Web of Science & $\begin{array}{l}\text { (TS=((preservice teacher* OR preservice educat* OR preservice trainer* OR } \\
\text { student teacher* OR teacher student* OR future teacher*) AND (sustainab* } \\
\text { awareness OR sustainab* literac* OR sustainab* competenc* OR sustainab* } \\
\text { conscious* OR sustainab* citizenship* OR "sustainab* behavi*r*) )) }\end{array}$ \\
\hline
\end{tabular}

\section{Screening}

Table 2

Screening criteria

\begin{tabular}{|c|c|c|}
\hline Criteria & Inclusion & Exclusion \\
\hline Time period & $2008-2018$ & Before 2008 \\
\hline Language & English & Other than English \\
\hline Country/Region & & None \\
\hline Literature type & Journal articles & $\begin{array}{l}\text { Books, book chapters, } \\
\text { conferences }\end{array}$ \\
\hline Subject area & Social Science & Other than social science \\
\hline
\end{tabular}

\section{Eligibility}

In order for the review process to be more accurate, a few eligibility and exclusion criterion are predetermined. Regarding literature type, only article journals with empirical data were selected excluding review article, book series, book, chapter in book and conference proceeding. Then, all non-English publication was also excluded in order to avoid confusion and also difficulty in the process of translation. The review process focused only on articles published in English. Also, with regard to timeline, a period of 10 years which is between 2008 and 2018 which is considered as an adequate time to view the research evolution in the publications. As the review process focused on sustainability among preservice teachers, only articles which are indexed in social science based indexes are selected, which means the reviewing process excludes articles that are published in a hard science index (Science Citation Indexed Expanded).

\section{Data abstraction and Analysis}

The selected articles which has gone through careful selection were analysed and assessed. In reviewing these articles, much efforts were focused on specific studies that responded to the formulated research questions. By reading the abstracts first, the data can be extracted then only the full articles were scrutinized in order to identify suitable themes 
and sub-themes. Qualitative analysis was performed by utilizing content analysis to identify themes related to preservice teachers' sustainable environmental behaviour. Then, the subthemes around the themes were established by using typology.

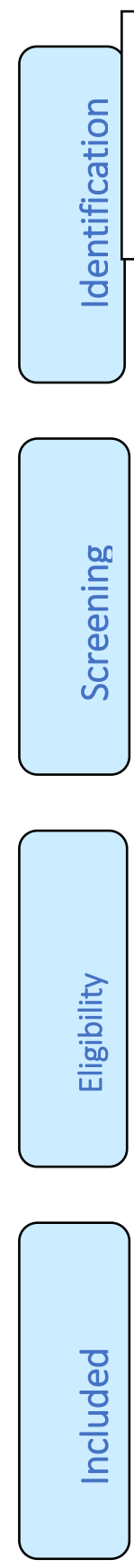

Records identified through database searching via Web of

Science

$(n=528)$
Records identified through database searching via Scopus

$$
(n=134)
$$

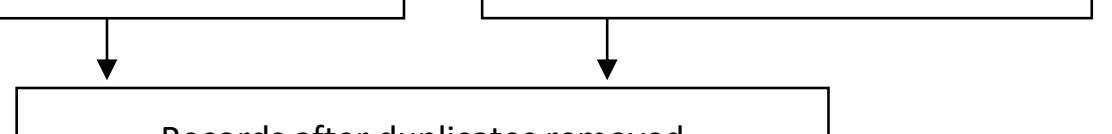

Records after duplicates removed

$$
(n=2)
$$

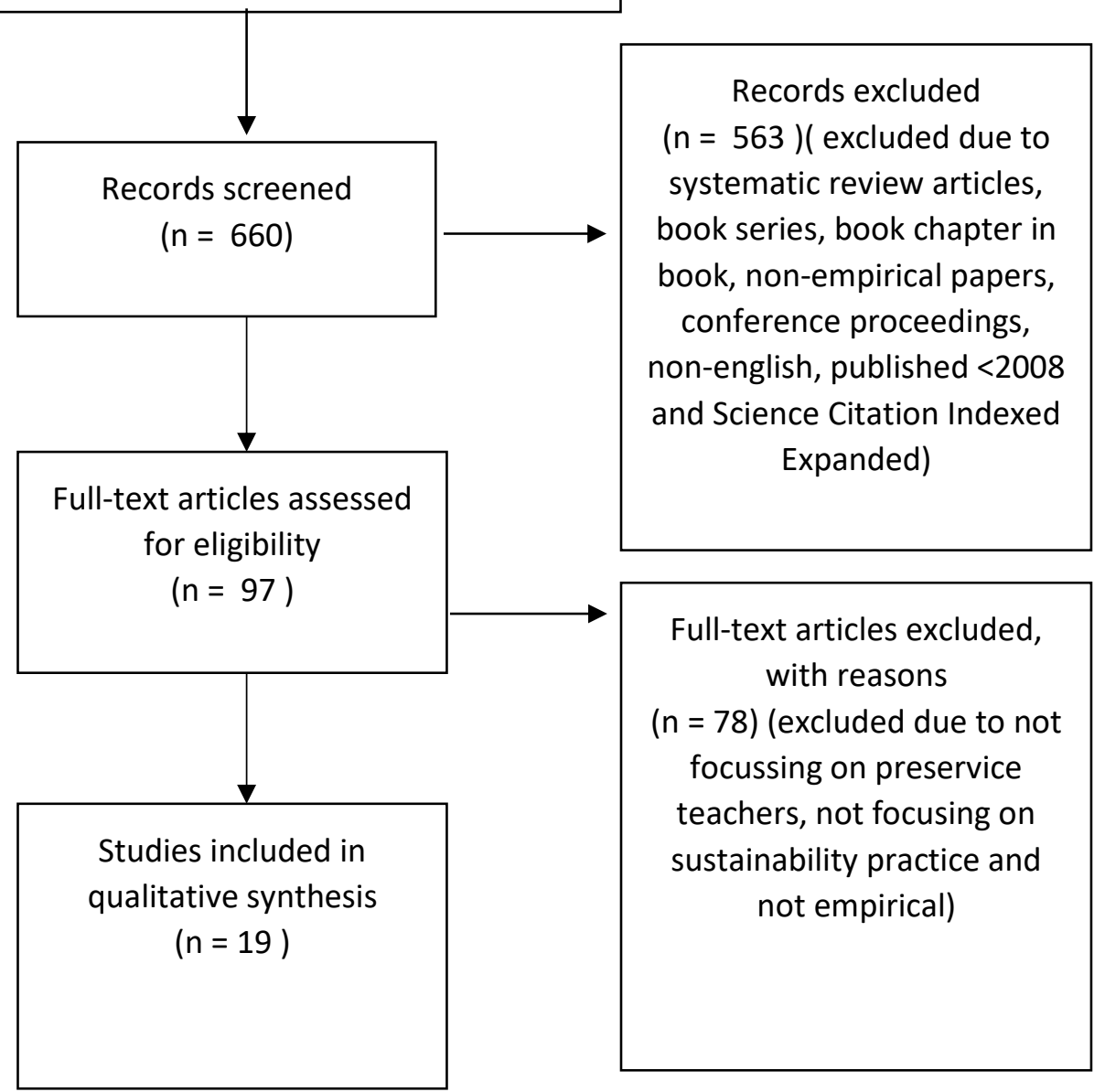

Adapted from:

Moher D, Liberati A, Tetzlaff J, Altman DG, The PRISMA Group (2009). Preferred Reporting /tems for

Fig. 1. Flow diagram of Preferred Reporting Items for Systematic Reviews. (PRISMA) 


\section{Outcome variables}

The terms sustainable competencies, sustainable behaviour and also sustainable consciousness, have been used widely and interchangeably to explain the practice of the sustainability concept. The first document that addressed the need of education as a tool to achieve sustainable development was Agenda 21 (United Nations, 2012). Sustainable development's aspiration requires the societies and citizens to come up with a solution to most problems caused by the human beings themselves. In terms of economic growth and wealth, it may seem like poverty rates are reduced, but it is inevitable that inequality, violence, and exclusion are still increasing across societies throughout the global arena. Unsustainable way of living and poor economic production and consumption are one of the main factors that contribute to global warming, environmental deterioration and natural disasters.

After selection of articles related to the desired field, the next process was categorising the articles based on the outcome variables. The outcome variables that were identified after the whole process of reading all the articles are presented. The number of article for each outcome variables is shown in Table 3.

\section{Table 3}

Breakdown of articles based on outcome variables

\begin{tabular}{lll}
\hline No. & Field of study & $\begin{array}{l}\text { Number } \\
\text { articles }\end{array}$ \\
\hline 1 & Sustainability Competencies & 3 \\
\hline 2 & Sustainable Behaviour & 2 \\
\hline 3 & Sustainable Consciousness & 2 \\
\hline 4 & Sustainability and Social Responsibility (SSR) Competencies & 1 \\
\hline 5 & Environmental Behaviour & 1 \\
\hline 6 & Sustainability Science & 1 \\
\hline 7 & Teaching about biodiversity conservation issues & 1 \\
\hline 8 & Implementation of ESD, challenges in ESD in TEls & 1 \\
\hline 9 & ESD Competencies & 1 \\
\hline 10 & Sustainable Consumption & 1 \\
\hline 11 & Environmental Literacy and Environmental Citizenship & 1 \\
\hline 12 & Pro-environmental behaviour & 1 \\
\hline 13 & Implementation of EE in Teacher Education Program & 1 \\
\hline 14 & Understanding of sustainability & 1 \\
\hline 15 & Perceptions on the concept of environment & 1 \\
\hline & Total & 19 \\
\hline
\end{tabular}




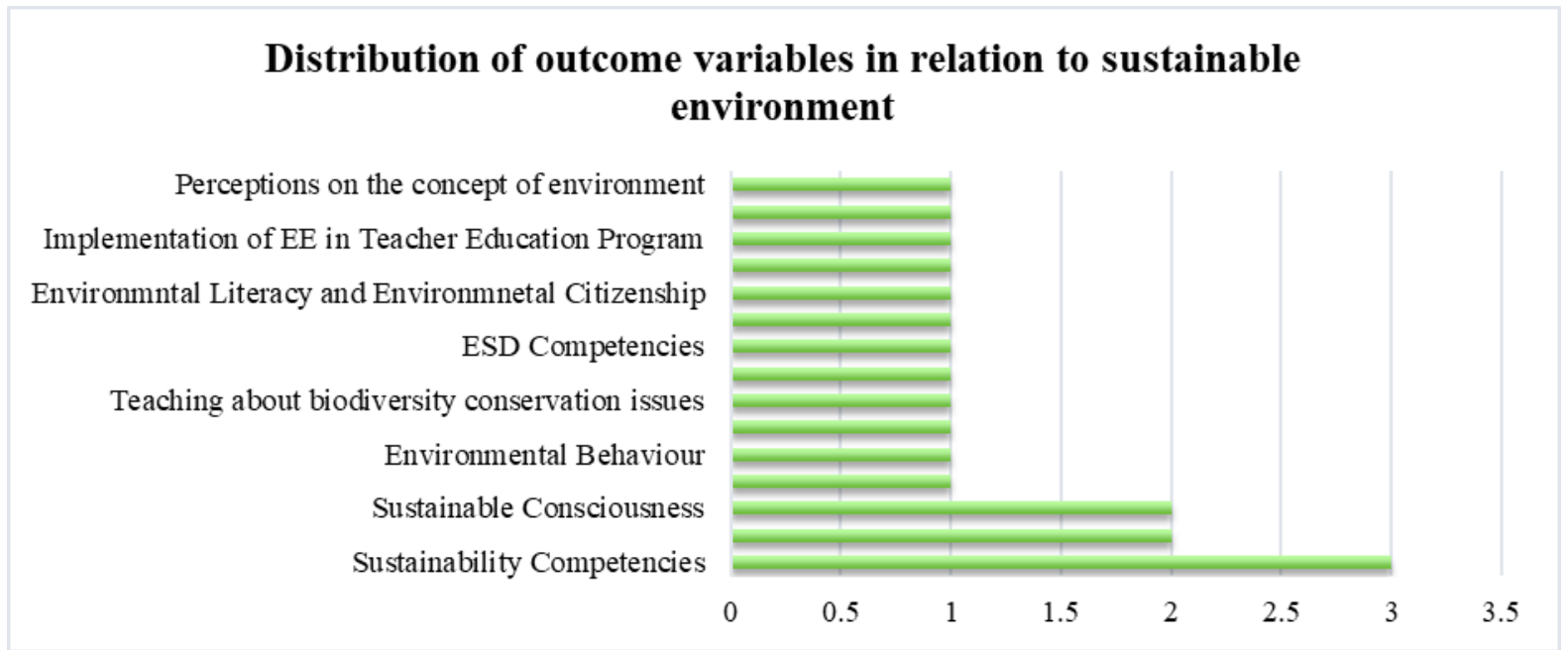

Fig. 2. Bar chart to demonstrate breakdowns of outcome variables in relation to sustainable environment

\section{Breakdown of Articles Based on Type of Method}

For this review, types of research methods are broadly classified into three categories according to the nature of the study and a few other characteristics. Types of research methods are divided into three main categories which are, quantitative, qualitative and mixed method. Given \& Lisa.M (2008) described quantitative research as the systematic empirical investigation of observable phenomena via statistical, mathematical, or computational techniques. On the other hand, qualitative research that depends on feelings, words, emotions, pictures, sounds and many other non-numerical and elements that are unquantifiable (Ghazali \& Sofean, 2018). In this type of study, "information is considered qualitative in nature if it cannot be analysed by means of mathematical techniques. This characteristic may also mean that an incident does not take place often enough to allow reliable data to be collected" (Yilmaz, 2013). In this study, to show the type of method the selected studies are divided into three types of methods, including: quantitative, qualitative and mixed method. The number of articles that are categorized into each type of study is shown in Table 4.

\section{Table 4}

Breakdown of articles according to data collection method

\begin{tabular}{lll}
\hline No. & Methodology & $\begin{array}{l}\text { Number } \\
\text { articles }\end{array}$ \\
\hline 1 & Qualitative & 10 \\
2 & Quantitative & 8 \\
3 & Mixed Method & 1 \\
& Total & 19 \\
\hline
\end{tabular}




\section{Data collection method}

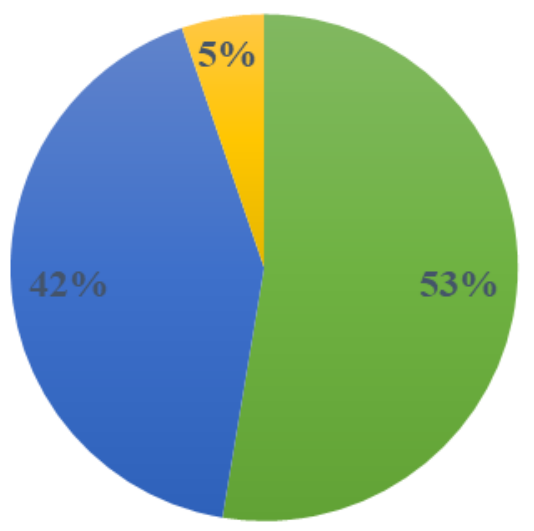

Qualitative $\quad$ Quantitative $\quad$ Mixed method

\section{Fig.3. Pie chart to demonstrate breakdown of data collection method}

\section{Breakdown of Articles by Journals}

Table 5 presents the results of articles that were grouped into the title of the journals. The articles related to sustainability and preservice teachers have been chosen from 8 scholarly journals indexed in the Web of Science and Scopus databases. Selected published articles, along with an extensive diversity of journals that focus on environmental sustainability limited to the respondents of pre service teachers, the willingness of different scholarly journals to publish in this field. The highest number of articles that the papers have been published in is Sustainability with 6 articles, followed by Environmental Education Research journal with 5 articles and International Journal of Sustainability in Higher Education with 3 articles. Teaching Education, Journal for Teacher Education for Sustainability, Journal of Geoscience Education, Journal of Cleaner Production, and Geoscience Education each published only 1 article.

\section{Table 5}

Breakdown of articles based on name of journals

\begin{tabular}{lll} 
No. & Name of Journal & $\begin{array}{l}\text { Number } \\
\text { articles }\end{array}$ \\
\hline 1 & Sustainability & 6 \\
2 & Environmental Education Research & 5 \\
3 & International Journal of Sustainability in Higher Education & 3 \\
4 & Teaching Education & 1 \\
5 & Journal of Teacher Education for Sustainability & 1 \\
6 & Journal of Geoscience Education & 1 \\
7 & Journal of Cleaner Production & 1 \\
8 & Geoscience Education & 1 \\
& Total & $\mathbf{1 9}$ \\
\hline
\end{tabular}




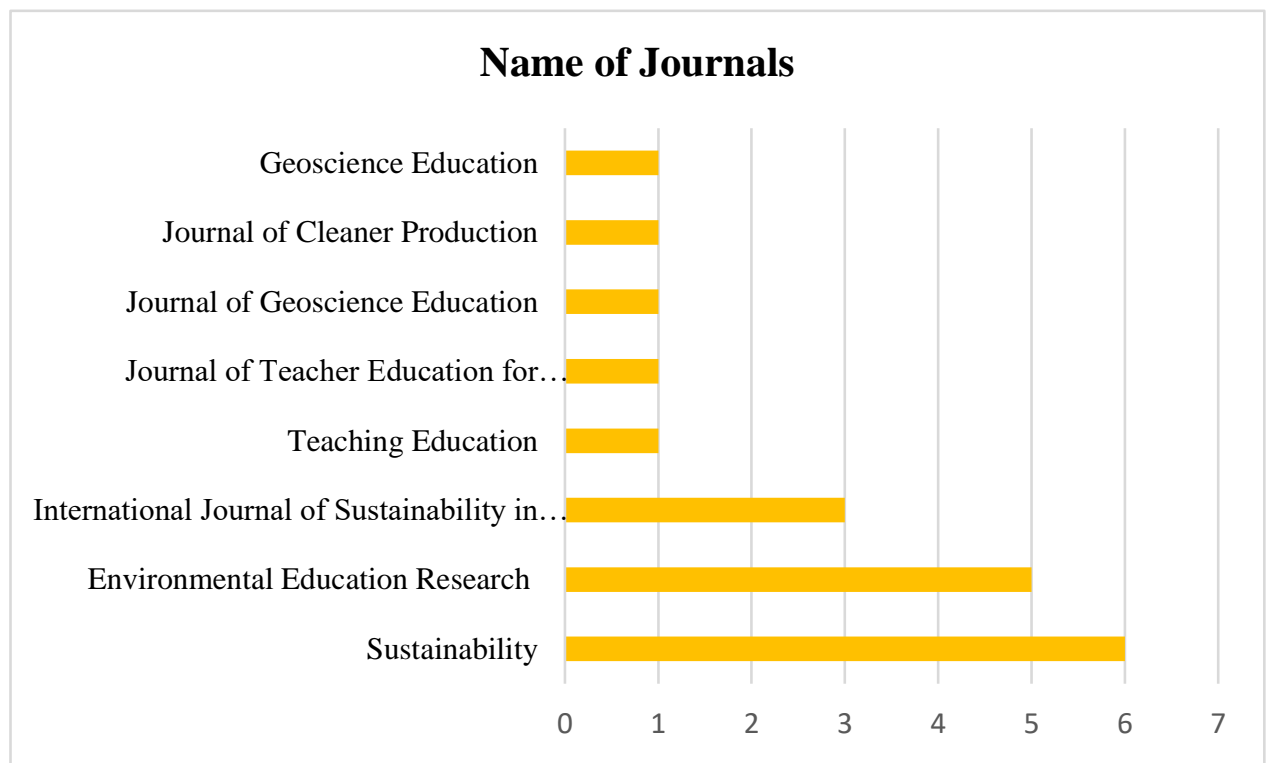

Fig. 4. Bar chart demonstrating breakdown of Name of Journals

\section{Breakdown of Articles by Year of Publication}

In recent decades, studies on Education for Sustainable Development have increased especially due to the post Decade of Education for Sustainable Development (DESD 20102014). Most studies are done among in-service teachers, school students, higher education students, graduate students and pre service teachers. This paper only focuses on the publications on this field among the pre service teachers from the year 2008 until 2018. The 10 -year period is adequate to observe patterns that are happening in the training for teachers' practice in the field of sustainability. Nevertheless, although the year selected in the search string was from 2008, the result that matches articles for this particular topic only ranges from year 2013 onwards. The number of articles published by year is demonstrated in Table 6 below.

\section{Table 6}

Breakdown of articles by year of publication

\begin{tabular}{lll} 
No. & Year of publication & $\begin{array}{l}\text { Number } \\
\text { articles }\end{array}$ \\
\hline 1 & Year 2013 & 2 \\
2 & Year 2014 & 1 \\
3 & Year 2015 & 4 \\
4 & Year 2016 & 3 \\
5 & Year 2017 & 5 \\
6 & Year 2018 & 4 \\
& Total & $\mathbf{1 9}$ \\
\hline
\end{tabular}




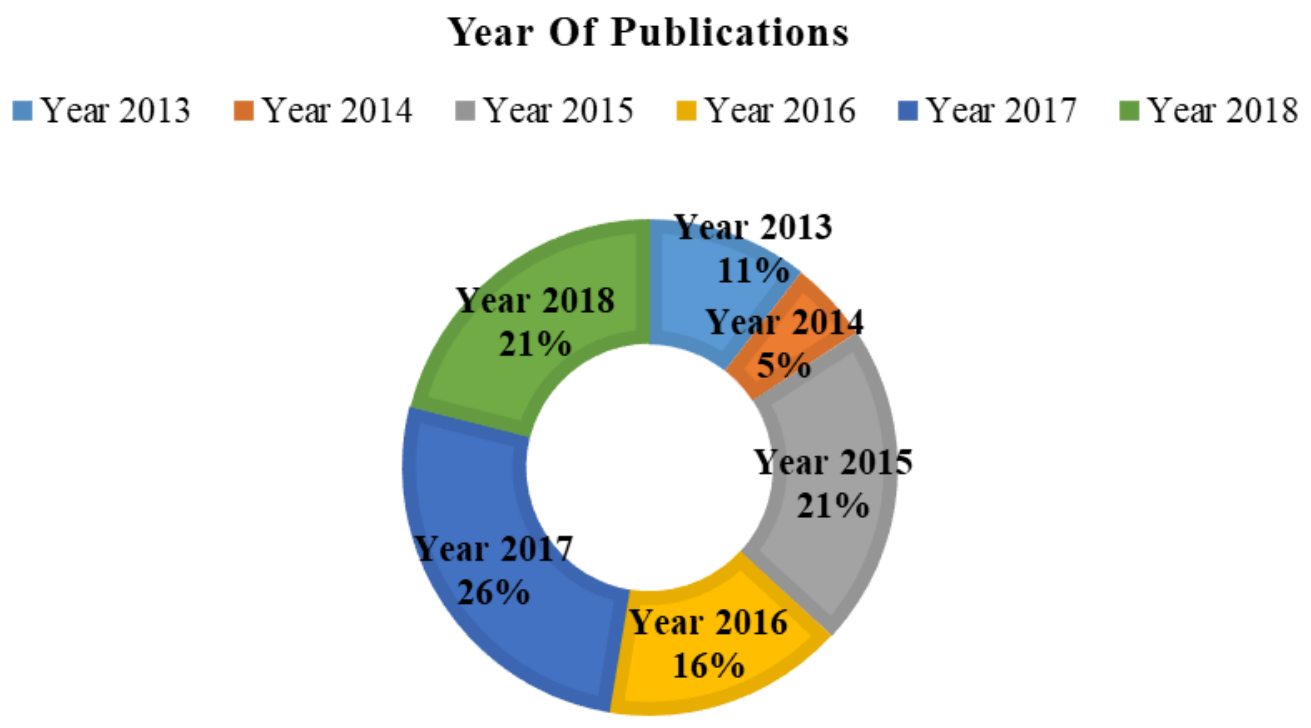

Fig. 5. Doughnut pie chart to demonstrate the breakdowns of article by year of publication

\section{Breakdown of Articles Based on Countries}

This systematic review also attempted to demonstrate the countries where the studies on sustainability among pre service teachers were carried out. The countries that have published five (5) articles on this area is Spain. Next, both USA and Israel came next with three (3) articles, followed by Italy, Pakistan, Germany, Finland, New Zealand, the Balkans, Vietnam and Iran with one article published on this particular area.

Table 7

Breakdown of articles by location of study

\begin{tabular}{lll}
\hline No. & Location of study & $\begin{array}{l}\text { Number } \\
\text { articles }\end{array}$ \\
\hline 1 & Spain & 5 \\
2 & United States of America & 3 \\
3 & Israel & 3 \\
4 & Italy & 1 \\
5 & Pakistan & 1 \\
6 & Germany & 1 \\
7 & Finland & 1 \\
8 & New Zealand & 1 \\
9 & Balkans & 1 \\
10 & Vietnam & 1 \\
11 & Iran & 1 \\
& Total & $\mathbf{1 9}$ \\
\hline
\end{tabular}




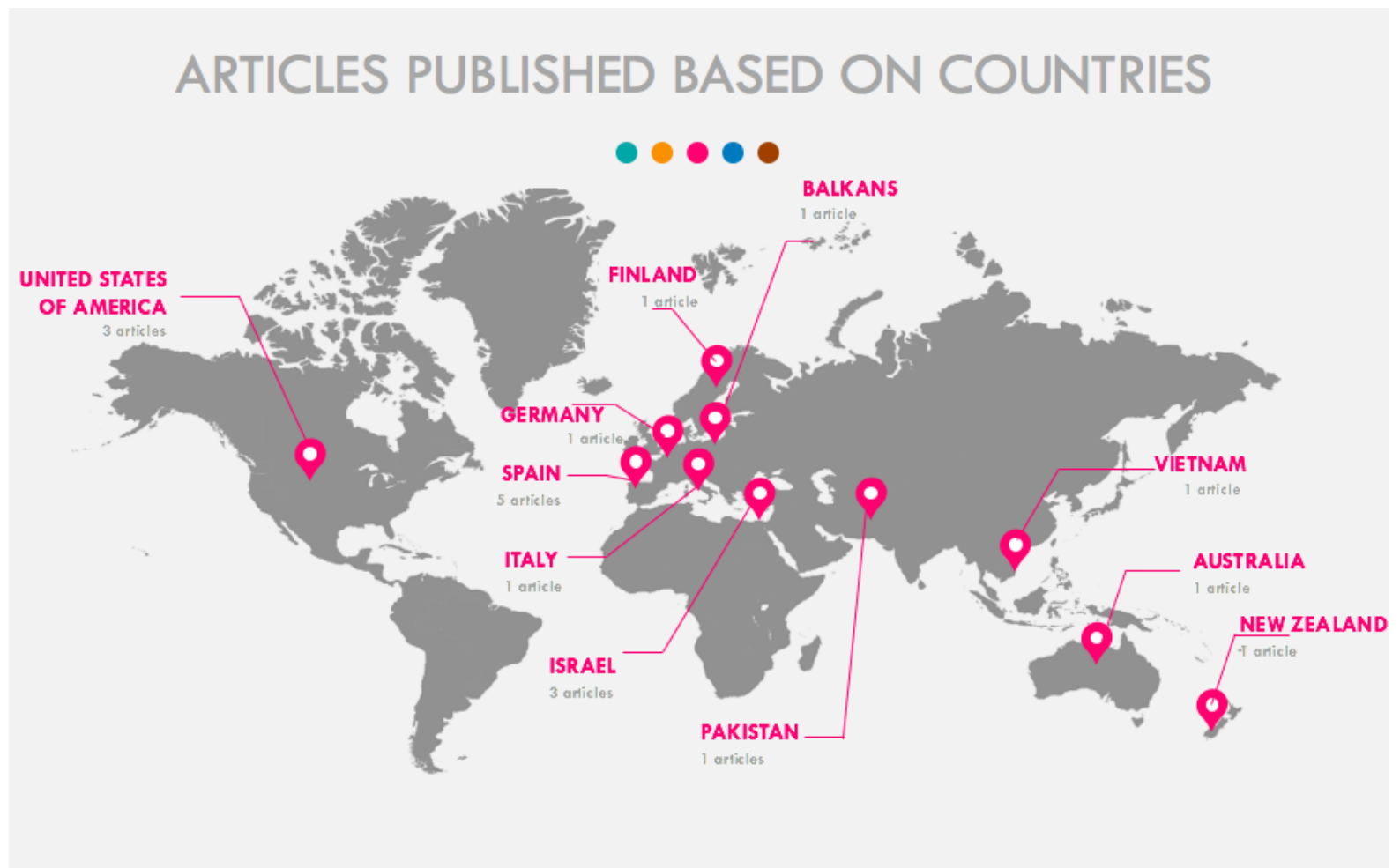

Fig. 6. Distribution of location of study

\section{Discussion}

Systematic literature reviews are very different from traditional conceptual reviews as they contain a thorough summary of the evidence available and are also quite transparent in selection of criteria. The inclusion and process of analysis needs to be transparent as to minimise the possibility of bias, and also to ensure that the level of reliability is much higher (Bryman 2008). For this particular review, only 19 articles meet the eligibility of the criteria selection although the total number of publications found by the search string was more than 500 publications. Careful selection had to be made in order to ascertain that the publications are accurately chosen.

The findings of this review revealed some interesting results of what is really happening in the field of education among future teachers. In 2013, Sally Birdsall revealed that the findings of her study provides an indication of the range of student teachers' understandings of sustainability and their self-awareness of their understandings despite their lack of formal education in this area. They provide evidence for the need for including sustainability education into initial teacher training programmes and a starting point for designing such courses that would enhance student teachers' understandings and assist in sustainability education programme design. In addition, it is inevitable that concrete competence components for the planning, implementation and evaluation of ESD teaching to be justified in an affirmative manner. Yavetza (2013) has also concluded that student teachers' understandings of environment still remained basic which shows us how important it is to reorient teacher-education programs toward environment and sustainability.

In a developing country like Vietnam, Thi Kinh Kieu, Jane Singer, Tracey Jean Gannon (2016) revealed that there is still a huge gap between awareness of ESD and ESD teaching capacity due to the systemic problems constitutional to Teacher Education Institutes including the teacher-based learning, classes with more than 40 students and poor facilities. In addition, the lecturers also stayed focused solely on the content-based teaching requiring 
the student teachers to memorize sustainability-related knowledge rather than building and developing the future teachers' competencies. Findings of a focus group discussion revealed that the pre service teachers do not have adequate competencies and skills related to ESD that would prepare them to instil sustainability in their teaching as they graduate and become real teachers. Most of the knowledge and skills are gained through non-formal education but rarely was integrated into the formal education by their lecturers. In 2017, Alkaher and Goldman discovered that undergraduate teacher programs need to improve their preparation of environmentally-literate educators. Significant component of teacher training is crucial, effective [environmental] education must also be anchored in a strong knowledge foundation. To conclude most of the findings revealed by the authors of every articles in this review, it is safe to say that teachers' education need to be revamped and reoriented as to highlight the importance of having sustainability in their future teaching career. Future teachers cannot neglect the fact that they need to educate the future nation on the importance of sustaining what the world is left to them. Future teachers also need to bear in mind that Environment Education or Sustainable Education is not a specific subject in most schools, therefore they need to be more creative in implementing and putting together their teaching materials. Preservice teachers have to know how to make teaching interesting as well as complimenting their lessons with current sustainability issues.

\section{Conclusion}

This paper presented a complete overview of the current study on sustainability in the field of teacher education. In addition, in this review paper, the results were interesting regarding the scope of studies. The article discusses the notion of the sustainability concept for teacher identity development during their years in the teacher education system where sustainable development is concerned. Adequate amount of literature assisted in the understanding of the solution to the inevitable crisis of global sustainability moreover in the field of education where teacher themselves, plays a significant role whether they realize it or not. This systematic review paper provides the compilation of studies in the development of sustainable environment behaviour during their years as teacher students.

Finally, compared to the research found in the literature, this paper contributes to the literature by analyzing the papers conducted by a certain category of respondents which are the pre service teachers. This is due to the fact that the research in this area has been done rigorously after the Talloires Declaration, Agenda 21, and Decade of Education for Sustainable Development (DESD). Most of the studies are conducted to evaluate the results of such programmes. In addition, this particular study, is compiling a complete collection of research papers which has been conducted empirically for Education for Sustainable Development. The result of this study can be quite interesting as the method of instilling sustainable environment behaviour among pre service teachers were comprehensively investigated for developing countries as well as developed countries such as USA, Australia and Spain. As a conclusion, this study analysed the publications on sustainability in various methodological aspects which can give insights to the researchers on what can and should be studied in the future.

\section{References}

Ashmann, S., \& Franzen, R. L. (2017). In what ways are teacher candidates being prepared to teach about the environment? A case study from Wisconsin. Environmental Education Research, 23(3), 299-323. 
Alkaher, I., \& Goldman, D. (2018). Characterizing the motives and environmental literacy of undergraduate and graduate students who elect environmental programs-a comparison between teaching-oriented and other students. Environmental Education Research. http://doi.org/10.1080/13504622.2017.1362372

Baniah Mustam. (2015). Penerapan Informal dan Formal Pendidikan Alam Sekitar di Suatu Kawasan Tercemar. University Malaya.

Barth, M., \& Michelsen, G. (2013). Learning for change: an educational contribution to sustainability science. Sustain Sci (2013) 8:103-119 DOI 10.1007/s11625-012-0181-5

Birdsall, S. (2014). Measuring student teachers' understandings and self-awareness of sustainability. Environmental Education Research, 20(6), 814-835. http://doi.org/10.1080/13504622.2013.833594

Bryman, A. (2012). Social Research Methods (4th ed.). Oxford.

Chinedu, C. C., Wan-Mohamed, W. A., \& Ogbonnia, A. A. (2018). A systematic review on education for sustainable development: Enhancing TVE teacher training programme. Journal of Technical Education and Training, 10(1).

Cebrián, G., \& Junyent, M. (2015). Competencies in education for sustainable development: Exploring the student teachers' views. Sustainability, 7(3), 2768-2786.

Hale, A. E., Shelton, C. C., Richter, J., \& Archambault, L. M. (2017). Integrating geoscience and sustainability: Examining socio-techno-ecological relationships within content designed to prepare teachers. Journal of Geoscience Education, 65(2), 101-112.

Huckle, J., \& Sterling, S. R. (Eds.). (1996). Education for sustainability. Earthscan.

Holdsworth, S., \& Thomas, I. (2016). A sustainability education academic development framework (SEAD). Environmental education research, 22(8), 1073-1097

Green, M. M. (2016). Preparing Pre-Service Teachers for Professional Engagement through Place/Community Pedagogies and Partnerships. Australian Journal of Teacher Education, 41(11), 44-60.

Green, M., \& Somerville, M. (2015). Sustainability education: Researching practice in primary schools. Environmental Education Research, 21(6), 832-845.

Gholami, J., Sarkhosh, M., \& Abdi, H. (2016). An Exploration of Teaching Practices of Private, Public, and Public-Private EFL Teachers in Iran. Journal of Teacher Education for Sustainability, 18(1), 16-33.

Gholami, J., \& Qurbanzada, I. (2016). Key Stakeholdersí Attitudes towards Teacher Education Programs in TEFL: A Case Study of Farhangian University in Iran. Journal of Teacher Education for Sustainability, 18(2), 5-20.

Jegstad, K. M., \& Sinnes, A. T. (2015). Chemistry teaching for the future: A model for secondary chemistry education for sustainable development. International Journal of Science Education, 37(4), 655-683.

Kalsoom, Q., \& Khanam, A. (2017). Inquiry into sustainability issues by preservice teachers: A pedagogy to enhance sustainability consciousness. Journal of cleaner production, 164, 1301-1311.

Kalsoom, Q., Khanam, A., \& Quraishi, U. (2017). Sustainability consciousness of pre-service teachers in Pakistan. International Journal of Sustainability in Higher Education.18(7), 1090-1107

Kieu, T. K., Singer, J., \& Gannon, T. J. (2016). Education for sustainable development in Vietnam: Lessons learned from teacher education. International Journal of Sustainability in Higher Education. 19(6), 853-874

Kieu, T. K., Singer, J., \& Gannon, T. J. (2016). Education for sustainable development in 
Vietnam: lessons learned from teacher education. International Journal of Sustainability in Higher Education. http://doi.org/10.1108/IJSHE-05-2015-0098

Lougen, C. (2011). Sources: The Sage Encyclopedia of Qualitative Research Methods. Reference \& User Services Quarterly, 49(1), 101-102.

Mei, N. S., Wai, C. W., \& Ahamad, R. (2017). Public environmental awareness and behaviour in Malaysia. Asian Journal of Quality of Life, 2(5), 43-53.

Moher, D., Liberati, A., Tetzlaff, J., Altman, D. G., \& Prisma Group. (2009). Preferred reporting items for systematic reviews and meta-analyses: the PRISMA statement. PLoS medicine, 6(7), e1000097.

Namunga, N. W., \& Otunga, R. N. (2012). Teacher Education as a Driver for Sustainable Development in Kenya. International Journal of Humanities and Social Science, 2(5), 228234.

Papuzinski A. (2018). The Enlightenment Assumptions of the Brundtland Report. Problemy Ekorozwoju - Problems of Sustainable Development 2018. Volume 13, No 1, 7-14

Pickering, C., \& Byrne, J. (2014). The benefits of publishing systematic quantitative literature reviews for $\mathrm{PhD}$ candidates and other early-career researchers. Higher Education Research \& Development, 33(3), 534-548.

Perez-Rodriguez, U., Varela-Losada, M., Álvarez-Lires, F. J., \& Vega-Marcote, P. (2017). Attitudes of preservice teachers: Design and validation of an attitude scale toward environmental education. Journal of Cleaner Production, 164, 634-641.

Tiana, S. A., \& Villarreal, A. A. (2016). A collaborative programme in sustainability and social responsibility. International Journal of Sustainability in Higher Education. 17(5), 719-736

Vega-Marcote, P., Varela-Losada, M., \& Álvarez-Suárez, P. (2015). Evaluation of an educational model based on the development of sustainable competencies in basic teacher training in Spain. Sustainability, 7(3), 2603-2622.

Yavetz, B., Goldman, D., \& Pe'er, S. (2014). How do preservice teachers perceive 'environment'and its relevance to their area of teaching?. Environmental Education Research, 20(3), 354-371. 